\title{
ANALYSIS OF THE VALUE SYSTEM IN THE CONTEXT OF THE INFLUENCE OF THE IDEOLOGY OF NEOLIBERALISM: THEORETICAL CONCEPTUALISATION
}

\author{
Cherniak K. V., \\ Master of the Department of Political Sociology \\ V. N. Karazin Kharkiv National University
}

The article is presented the analysis of the ideology of neoliberalism from the perspective of the investigation of its influence on the value system. Particularly, theory and history of neoliberalism are considered and cross-cultural studies of value systems are analyzed. On this basis the author model of the value system for the investigation of the value system in the context of the influence of the ideology of neoliberalism is formulated and tested.

У статті представлений аналіз ідеології неолібералізму з перспективи вивчення ії впливу на систему цінностей. Зокрема, розглянуто теорію та історію неолібералізму, проаналізовано кроскультурні дослідження системи цінностей та на цій базі сформовано та перевірено авторську модель системи цінностей із метою вивчення системи цінностей у контексті впливу ідеології неолібералізму.

В статье представлен анализ идеологии неолиберализма с перспективы изучения ее влияния на систему ценностей. В частности, рассмотрены теория и история неолиберализма, проанализированы кросс-культурные исследования системы ценностей и на этой базе сформирована и проверена авторская модель системы ценностей для изучения системы ценностей в контексте влияния идеологии неолиберализма.

Key words: neoliberalism, ideology, value system, cross-cultural studies.

Today neoliberalism is one of the most expanded and discussed ideologies, but at the same time one of the least investigated ones. From the very beginning of its development both its proponents and critics have mentioned the great influence that neoliberalism has on political, economical and other spheres of the social life-sustaining activity. Many scholars, especially critics of the modern society such as F. Jameson, N. Chomsky, G. Lipovetsky, I. Wallerstein and others have specified in their works different characteristics that have been appeared in the society exactly under the influence of neoliberalism. They have also studied politicians' actions that are referred to the expansion of neoliberalism (specifically, in so-called Western countries).

Nevertheless, all these generalizations are not always based on an empirical analysis of the society and social processes. In most cases scientists limit the study to socio-historical and statistical analysis, analysis of the official documents, secondary data analysis and rarely - analysis of the opinion of experts (usually opinions of other scientists). Consequences that have been results of the cabinet analysis are extended on the whole society and on its value system. However, it is necessary to investigate the value system and its changes in the context of the influence of the certain ideology to infer about the influence of this certain ideology on the society and its value system. The explorers of neoliberalism usually do not do this. Therefore, it can be maintained that there is a contradiction between the confidence of some sociologists about the massive influence of neoliberalism on the society and social processes and the lack of the empirical evidences of this confidence.

Another feature of the study of neoliberalism and its influence on the society that stipulates the applicability of the chosen topic is concerned with fact that usually neoliberalism is considered as a monolithic phenomenon. However, it can be divided at least in three separate parts - ideology, economic and politics. The generalized consideration of neoliberalism as the undivided entire makes it impossible to study neoliberalism and its features because not neoliberalism but some kind of a theoretical replica is analyzed. This situation denies the opportunity to investigate the influence of the ideology of neoliberalism on the public consciousness and discredits theoretical conclusions that are made in this area.

Hence, sociological knowledge about the character of the existence of neoliberalism in the public consciousness and the investigation of its influence on the value system and its parts has left extremely limited and inaccurate. 
Given that the influence of the ideology of neoliberalism on the value system is the low-studied topic that does not have a sufficient theoretical foundation for a further empirical analysis, in this article the attention is paid to the gnosiological aspect of the problem situation which is the absence of sociological knowledge about the character of the influence of the ideology of neoliberalism on the social value system and the absence of the investigatory sociological framework for the studying of the influence and the understanding of neoliberalism exactly as the ideology and not as the political or economic doctrine.

Therefore, the aim of the study is the creation of the sociological framework for the analysis of the value system in the context of the influence of the ideology of neoliberalism.

Neoliberalism in a broad sense begun to form as far back as 1950s in a group of scientists - members of the Mont Pelerin Society [1]. From the second part of 1970s it was actively extended as a new doctrine that is the only guarantee of freedom and the solution of economic and social problems. It was and is adopted both in developing countries and in so-called Western countries (although I. Wallerstein has mentioned that neoliberalism was actively developed in this region in 1990s but then part of the countries have coming back to the protectionism [2]).

Based on theories of D. Harvey [3], N. Chomsky [4], N. Klein [5], I. Wallerstein [6], M. Prasad [7] and P. Kutuev [8] with the use of ideas of M. Friedman [9] and F. Hayek [10] the conclusion has been made that the history and the theory of neoliberalism can be examined from several positions: apologetic theory and oppositional theory; development of neoliberalism in developed countries and in developing countries; development of neoliberalism in politics, economy, culture and world view. Such approach allows to find out that neoliberalism not only theoretically studied but exists at several different levels and in several manifestations in reality, among other things separately as economic doctrine, political doctrine and ideology. This distinction is important not only for conceptual emphasizing of neoliberalism as ideology but also because neoliberalism in different forms is adopted and influence differently. That leads to the situation when the term is used to describe different ideas, often even opposite (for example, economical neoliberalism that is adopted in developed countries and in developing countries have highly different forms, instruments and consequences).

Based on the theories of the investigation of neoliberalism mentioned above and on the approaches of the studying of ideology of K. Marx [11], F. Engels [11], A. Gramshi [12], L. Althusser [13] and P. Bourdieu [14] the following operational definition was formulated: the ideology of neoliberalism - one of the sects of the ideology of liberalism that appeared in 1970s and defends supreme market freedom, a limitation of government activities to the guarding of borders and the control of implementation of legislation, and encourages the concentration of the thought of an individual on themselves, their achievements and their satisfaction. The ideology of neoliberalism is the ideology that appeared 'from above' with a claim of being a new (illusive) world view. Main principles of the ideology of neoliberalism also have been defined: supreme market freedom; naturalness of the existence of a competition and a fighting for a best position; dependence of successes and failures on personal abilities and insistence; freedom of a preparation of labor forces beyond the borders of a government control; weakening of a government protectionist politic; intensification of the processes of a free capital, products and labor forces flow; standardization of consumption, culture, education; support of the freedom of speech, thought, gathering, movement and travel; defense of human rights; democratic rule.

The ideology of neoliberalism (as well as any other ideology that acts beyond the scope of the field of politic) is connected with the value system at the level of so-called 'daily ideology' (using a typology that divide ideologies on 'political' and 'daily'). The content of the daily ideology was described good by S. Zizek who mentioned that ideology is not just a system of ideas but it also appeares in the way people percept the world around, how they organize the life, in their manners, behavior, acceptance or non-acceptance of anything [15]. Values also are included in this list and can be defined as "ideals, interests, goals, persuasions and other worldview aspects that are formed together with a digestion of a social experience" [16]. Such scholars as P. Bourdieu [14], K. Martinenko [17], M. Freeden [17] and I.V. Strelnikov [18] have pointed the great influence that ideology has on a formation of values and value system both of an individual and a society in whole.

To form the sociological framework of the studying of the value system in the context of the influence of the ideology of neoliberalism it has been chosen to create a separate model of a value system that is consisted of certain value orientations. This decision is based, firstly, on the understanding of the value system as a complex of values and value orientations that are ordered by the importance degree [19], and on the understanding of the value orientations as a structural connection between values and a value-oriented subject (individual, group etc.) [16]. Secondly, in the long-term the research is related to the studying of the value system of a society and groups of societies. For this reason there has been decided to create the model according to existed cross-cultural studies, notable, those ones that include certain value dilemmas which have to be universal and understandable in studied cultures [20].

Particularly, for the creation of the model there have been chosen several studies: cultural dimensions theory of G. Hofstede [21]; method of the comparison of cultures of C. Kluckhohn [22]; conception 
of the comparison of national cultures of $\mathrm{F}$. Trompenaars [23]; theory of cultural syndromes of $\mathrm{H}$. Triandis [24]. Theories have been chosen using one important criterion - they allow to create the model of value dilemmas/orientations specifically for the analysis of the value system in the context and under the (potential) influence of the ideology of neoliberalism and to trace the presence (or absence) of changes of value orientations exactly in the context of the development and expansion of neoliberalism.

It is worth explained that there was made a deep theoretical analysis of characteristics of neoliberalism (on the base of authors mentioned above in the context of studying neoliberalism) to understand which value orientations are necessary for the model been created. The list of values and models of behavior that are used to describe neoliberalism was formed. Then this list was divided into a few thematic categories. These categories were compared to the existed models and there was find out that all categories (except one) coincided meaningfully with value orientations that have been already created in different cross-cultural studies.

Thus, four from six value orientations have been taken from the Hofstede's renewed theory - "power distance", "individualism versus collectivism", "uncertainty avoidance" and "long term orientation versus short term normative orientation". From the Kluckhohn's method have been chosen one dilemma - "independence versus dependence", and it was modified to "independence versus dependence" referred to government as this is one of the most important topics for neoliberalism. The conception of Trompenaars is interesting for this work as a supplement to the value dimension "long term versus short term orientation". Trompenaars described this orientation deeper than Hofstede and emphasized that it means the focus or on a today's life and short-term perspective, or on the future and long-term perspective. Triandis's theory is useful in the way how he sees the "individualism versus collectivism". Triandis is the only cross-cultural scientist who excretes two levels of this dilemma - horizontal and vertical. It can be supposed in this research too that both individualism and collectivism can appear on different levels and exist in one society parallelly, not harming each other.

Except these five chosen value orientations one orientations was created and added to them. It is conditioned by the fact that several values that was defined on the theoretical level and that are promoted by the ideology of neoliberalism, could not be included in any of the orientations that were created by other scientists, and they also had the same topic area. This value orientation is called 'material orientation - orientation to non-material'.

Combined all chosen and created value orientations, the following model of value orientations for the investigation of the value system in the context of the ideology of neoliberalism has been formed:

1. Power distance. Under this category Hofstede understands a level of an unequal division of power in a society. It helps to define whether there is the unequal division of power in society and how it is displayed. Opponents of neoliberalism have been stated that this phenomenon encourages growth of a disruption between the society and power and encourages an establishment of non-governmental organizations (NGO) as a formal mediator in conversation between power and the society. "Power distance" also includes investigation of possible consequences of an increase of an unequal allocation of power that are committed as results of the influence of neoliberalism - political apathy of citizens, growth of a popularity of NGOs and a decrease of trust to power and politicians. This orientation is interesting and important to analyze also because there exists a clear contradiction between theory of neoliberalism that claims that this phenomenon encourages a participation of citizens in politics, and critical theory that insists upon an opposite tendency.

2. Uncertainty avoidance. This orientation is directed to find out whether the ideology of neoliberalism influence an attitude to ambiguous and tentative situations. In the theory and handlings of neoliberalism the idea is promoted that it leads to an increase of ambiguity and tentativeness in society. It is manifested in short-term contracts, permanent competition, presence of constant danger of terroristic acts, mainstreaming of an equal treatment to every culture etc. Here the task is to study the attitude to different situations of ambiguity and the existence of a feeling of certainty or uncertainty. It is worth mentioned that in this orientation a collision between two opposite values can happen. For example, on the one hand, theory of neoliberalism promotes multiculturalism, but, on the other hand, it advocates standardization and unification of styles, way of living, education system.

3. Individualism versus collectivism. By these orientations presence or absence of a move to individualism is analyzed. In accordance to the theory of neoliberalism this ideology conduces to the individualization of society, more specifically - individuals, their orientation to their own prosperity and prosperity of their close people without taking into account positions of other people and even to the bad for them. In such a way neoliberalism develops hedonism, brings to the forefront individual freedoms, rights and interests, facilitates self-investigation, creation of own comfort and increase of a quality of own life. It should be mentioned again that this dimension of the model is based on the Triandis's theory and includes two types of individualism and two types of collectivism that has to be separated during the analysis of empirical data. 
4. Long-term orientation versus short-term orientation. Although Hofstede defined these orientations and primary the decision to take them was based on his theory, the explanation of Trompenaars for such dimension is substantially more correspond to the analysis of the value system in the context of the ideology of neoliberalism. The usage of these orientations helps to define to which type, following the theory of Trompenaars, the culture of analyzed society is related - synchronous or consistent. Analysts of neoliberalism maintain that it has influenced the formation of consistent cultures that focus on a short-term planning and today's achievements. To confirm this fact short-term contracts at work, big amount of people who rent flats instead of buying, dominance of hedonism in the way of satisfying own needs here and now are cited as examples. Through these orientations will be analyzed which orientation people prefer, which use in life and which attitudes they have towards long-term and short-term orientations.

5. Independence versus dependence from the government. It was mentioned above that this orientation was previously taken from the Kluckhohn's method but he used it to describe relations between people. In the created model this orientation works as an instrument to describe the opinion about the role of the government in different spheres of life. This orientation is important because one of the main principles of neoliberalism is a decrease of the governmental influence almost in all spheres of life except directly political responsibilities and protection of the state territory. Through the analysis of this dimension it is possible to examine attitudes to such characteristics of neoliberalism as a free market, a private property, privatization (including privatization of health care, pension fund, education, social protection, military sphere etc.), a decrease of taxes, a decrease of labor unions influence.

6. Material orientation - orientation to non-material. These value orientations are based on the values that were not suitable for any other already created dimensions but were all associated with one topic - materiality in the meaning of things and finance. There are such characteristics as pragmatism, utilitarianism, commercialization, consumerism, increasing importance of the income, success at work and material (financial) success. That is why there was a need to create one more dimension. With the adding of such orientations the model also allows analyzing presence or absence of a move to material value and the level of importance of these values.

The pilot research of the value system in the context of the ideology of neoliberalism has been conducted to test the model at the empirical level. The data set of four waves of European Value Study has been chosen as a primary data for analysis. The analysis has included countries of European Union only to guarantee more or less homogenous group of societies. In the EVS questionnaire five questions have been chosen to test every value orientation in the model. Every question has had to be used in at least three from four waves. On this basis the comparison of means of answers in different waves has been made. The pilot analysis has shown that the created model works - it demonstrates the dynamic of value orientations and value system in the context of the influence of the ideology of neoliberalism. Moreover, even at the level of the pilot study has been proved the statement of I. Wallerstein that the top point of the popularity neoliberalism achieved in 1990s and then it has decreased.

Hence, based on the analysis of the theory and history of neoliberalism expounded by D. Harvey, N. Klein, N. Chomsky and I. Wallerstein, on the one hand, and the analysis of theories of the comparison of cultures in cross-cultural studies of G. Hofstede, C. Kluckhohn, F. Trompenaars and H. Triandis, on the other hand, the ideology of neoliberalism was separated as a specific phenomenon and the special model of value orientations that allows to analyze the value system in the context of the ideology of neoliberalism was created.

Although neoliberalism is a popular topic in political and social sciences during last decades, the ideology of neoliberalism has left less-studied phenomenon. The existence of neoliberalism as the ideology is corroborated both by the theory of neoliberalism that contains ideological elements of neoliberalism and by the actions of politicians and scientists in the context of the adoption of neoliberalism that are oriented to internalization of neoliberalism at the level of the public conscious. Since the creation of hypothesis and the drawing of conclusions referring the ideology of neoliberalism and its influence on a society is nowadays possible only on the base of the secondary data mentioned above, it was decided to create the sociological framework for studying exactly the ideology of neoliberalism. The first step to creation such a framework has become the model of the value system that allows studying the value system specifically in the context of the ideology of neoliberalism. This model can be used to compare one society in different periods of time as well as several different societies in one period of time to define the cultures that are more or less oriented to neoliberal values (the interesting way of the research can be the testing of the availability of the model to analyze the value system in the context of other ideologies that claimed or claim to become a worldview).

The emphasizing of the ideology of neoliberalism as a separate form of neoliberalism offers wide challenges to more detailed and theoretically grounded investigation and understanding of neoliberalism as a complex phenomenon. In terms of more substantial abilities of the analysis, the model that was created allows to conduct a research of a state and changes of the value system in the context of the ideology of neoliberalism both in a one society and in a variety of societies with different social and historical background. 


\section{References:}

1. Treanor P. Neoliberalism: origins, theory, definition. Reading list, Goldsmiths, University of London. 2005. URL: http://web.inter.nl.net/users/Paul.Treanor/neoliberalism.html

2. Валлерстайн И. Канкун: конец неолиберальной агрессии / Пер. с англ. М. Десятовой. URL: https://scepsis.net/library/id_260.html.

3. Harvey D. A Brief History of Neoliberalism. Oxford University Press. 2005. 256 p.

4. Chomsky N. Profit Over People: Neoliberalism and Global Order. New York u.a. : Seven Stories Press, 1999. $175 \mathrm{p}$.

5. Klein N. The Shock Doctrine: The Rise of Disaster Capitalism. London u.a. : Lane. 2007. 558 p.

6. Wallerstein I. The End of the Word As We Know It: Social Science for the Twenty-First Century. Minneapolis, Minn. u.a. : Univ. of Minnesota Press. 2003. 277 p.

7. Прасад М. Лекції у КПІ ім. І. Сікорського на теми «Неолебіералізм у світі: оцінка теорій», «Теорія

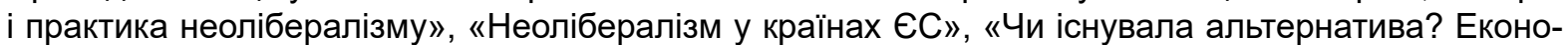
міка неолібералізму» / Кафедра соціології НТУУ «Київський політехнічний інститут» ім. І. Сікорського. URL: http://www.sociology.kpi.ua/seminars-2018?lang=ru.

8. Кутуєв П.В. Трансформації модерну: інституції, ідеї, ідеології : монографія. Херсон : Видавничий дім «Гельветика», 2016. 516 c. URL: http://www.sociology.kpi.ua/wp-content/uploads/2019/01/ Кутуєв-ТРАНСФОРМАЦІї-МОДЕРНУ.pdf

9. Friedman M. \& Friedman R.D. Capitalism and Freedom. Chicago u.a. : Univ. Press, 1969. 202 p.

10. Hayek F.A. The Road to Serfdom. Chicago, III : Univ. of Chicago Press, 1944. 250 p.

11. Маркс К., Энгельс Ф. Немецкая идеология. Сочинения, изд. 2. Т. 3. Москва : Государственное издательство политической литературы, 1955. С. 7-544.

12. Filippini M. Using Gramsci: A New Approach. Translated by Patrick J. Barr. Pluto Press, 2017. 176 p.

13. Althusser L. On Ideology. London u.a. : Verso, 2008. 179 p.

14. Бурдье П. О символической власти. Социология социального пространства. Москва : Ин-т экспериментальной социологии; Санкт-Петербург : Алетейя, 2007. С. 87-96.

15. Корецкий В., Рузаев Д. Интервью со Славоем Жижеком. Colta.ru. URL: http://archives.colta.ru/ docs/20836.

16. Сурина И.А. Ценностные ориентации. Знание. Понимание. Умение. Энциклопедия гуманитарных наук. 2005. № 4. С. 162-164.

17. Алексеенко О.И. Политология : учеб. пособие для юрид. вузов и фрак. / О.И. Алексеенко, А.П. Андреев, Г.И. Воробьев, С.А. Даниелян; под общ. ред. Воробьева Г.А., Мартыненко К.М. Краснодар : [б. и.], 1995. 394 с.

18. Стрельников И.В. Политическая идеология: актуальность ценностного похода. Теория и практика общественного развития. 2015. № 10. С. 122-126.

19. Елишев С.О. Теоретико-методологические подходы к изучению понятий «ценность», «ценностные ориентации». Вестник Московского университета. Серия 18. Социология и політологія. 2010. № 3. C. 74-90.

20. Мурадян О.С. Індивідуалізм та комунітаризм як ціннісні засади способу життя : дис. ... канд. соціол. наук : 22.00.01. Харків : Б.в., 2011. 223 с.

21. Хофстеде Г. Модель Хофстеде в контексте: параметры количественной характеристики культур / Пер. с англ. В.Б. Кашкина. Язык, коммуникация и социальная среда. 2014. Выпуск 12. С. 9-49.

22. Емельяненко Т.В. Методы межкультурных исследований цінностей. Социология: методология, методы, математическое моделирование (4M). 1997. № 9. С. 32-54.

23. Trompenaars F. \& Hampden-Turner C. Riding the waves of culture: understanding cultural diversity in business. London, Nicholas Brealey Publishing Ltd. 1997. 265 p.

24. Гарванова М.3., Гарванов И.Г. Исследование ценностей в современной психологи. Современная психология : материалы III Междунар. науч. конф., г. Казань, октябрь 2014 г. Казань : Бук, 2014. C. 5-20. 